\title{
Size selectivity of gill-nets and growth of roach Rutilus rutilus (Linnaeus, 1758) an alien species in Piediluco lake (Italy)
}

\author{
D. Giannetto ${ }^{(1), \star}$, A. Carosi $i^{(2)}$, L. Ghetti( ${ }^{(3)}$, L. Pompei $i^{(1)}$, P. Viali(2), M. Lorenzoni ${ }^{(1)}$
}

Received August 4, 2013

Revised January 7, 2014

Accepted January 7, 2014

\begin{abstract}
Key-words: growth, gill-net selectivity, alien species, euthrophic lake, fisheries management

The analysis of catch selectivity of fishing equipment is a crucial step for the management of alien species in freshwater ecosystems. Roach Rutilus rutilus was introduced in many waterways in Italy often becoming the dominant species of the fish community and it is now considered potential pest. In Piediluco lake the species was first found in 2004 and its abundance has increased at a level that creates concern for the other fish species present in the lake. The growth of $R$. rutilus and the selectivity of gill-nets on its population were examined in Piediluco lake by analysing the selectivity of gill-nets of different mesh size. Sampling was conducted from January 2011 to October 2012 by means of gill-nets of differentsized mesh $(8,10,12.5,15.5,19.5,24,28,35,45$ and $55 \mathrm{~mm})$. The results showed that $R$. rutilus in Piediluco lake had a growth faster and higher than in many other lake environments. The results of gill-nets selectivity gave important information to design a plan to control this species and confirmed that the use of suitable fishing techniques could be useful to manage the population of this alien species in Piediluco lake as well as in other similar environments.
\end{abstract}

\section{ABSTRACT}

\section{RÉSUMÉ}

Sélectivité en taille des filets maillants et croissance du gardon Rutilus rutilus (Linnaeus, 1758), une espèce exotique au lac de Piediluco (Italie)

Mots-clés : croissance, sélectivité, filet maillant, espèce exotique, lac eutrophe, gestion des pêches
L'analyse de la sélectivité des captures du matériel de pêche est une étape cruciale pour la gestion des espèces exotiques dans les écosystèmes d'eau douce. Le gardon Rutilus rutilus a été introduit dans de nombreux cours d'eau en Italie, devenant souvent l'espèce dominante de la communauté de poissons et il est maintenant considéré comme nuisible potentiel. Dans le lac de Piediluco l'espèce a été découverte en 2004 et son abondance a augmenté à un niveau qui suscite des inquiétudes pour les autres espèces de poissons présents dans le lac. La croissance de $R$. rutilus et la sélectivité des filets maillants sur la population ont été examinées au lac de Piediluco par l'analyse de la sélectivité des filets maillants de maillages différents. L'échantillonnage a été effectué de janvier 2011 à octobre 2012 au moyen de filets maillants de différentes mailles $(8,10,12.5,15.5,19.5,24,28,35,45$ et $55 \mathrm{~mm})$. Les résultats ont montré que $R$. rutilus du lac de Piediluco a connu une croissance

(1) Dipartimento di Biologia Cellulare e Ambientale, Università di Perugia, via Elce di Sotto, Perugia 06123, Italy

(2) Provincia di Terni, Servizio Agricoltura Caccia e Pesca, Via Plinio il Giovane, 21-05100 Terni, Italy

(3) Regione dell'Umbria, Servizio Programmazione Forestale, Faunistico-Venatoria ed Economia Montana, via M. Angeloni, 1-06124 Perugia, Italy

* Corresponding author: danielagiannetto@libero.it 
plus rapide et plus élevée que dans beaucoup d'autres milieux lacustres. Les résultats de la sélectivité des filets maillants ont donné des informations importantes pour concevoir un plan pour contrôler cette espèce et a confirmé que l'utilisation de techniques de pêche appropriées pourrait être utile pour gérer la population de cette espèce étrangère dans le lac de Piediluco, ainsi que dans d'autres environnements similaires.

\section{INTRODUCTION}

The introduction of alien species has dramatically changed many ecological communities and contributed to species extinctions (Byers et al., 2002). In recent times this phenomenon has become particularly widespread in aquatic ecosystems due to the increase in aquaculture and stocking programs and it is considered to be one of the greatest threats for biodiversity and for the integrity of native communities (Mack et al., 2000; Helfman, 2007).

In the last two centuries, alien fish species have been introduced into European freshwater systems for purposes of sport, aquaculture and ornament (Welcomme, 1988). Once established, many introduced species expand their geographical ranges within the region of introduction with both direct and indirect effects that can cause both economic damage and irreversible ecological changes (Andersen et al., 2004). When alien species are introduced, biodiversity generally declines. The result is that only a few species, proliferate: the less specialist and more able to adapt to a broad range of habitats, (McKinney and Lockwood, 1999) affecting the indigenous or less adaptable ones (Giannetto et al., 2012)

In Italy, the introduction of alien fish species has brought a progressive loss of the zoogeographic identity of native fish assemblages (Bianco and Keitmaier, 2001). With regard to Piediluco lake (Central Italy), the original composition of the fish population has undergone significant changes in recent years, mainly as a result of environmental deterioration due to the eutrophication of water (Cioffi and Gallerano, 2000) and the introduction of alien species (Lorenzoni et al. 2009). While some species such as European perch Perca fluviatilis Linnaeus, 1758 and whitefish Coregonus lavaretus (Linnaeus, 1758) were introduced in order to sustain commercial fishing (Riccardi, 1955), others, including roach Rutilus rutilus (Linnaeus, 1758), were accidentally introduced into the lake.

R. rutilus is a member of the Cyprinidae and is native in Europe (north to Pyrenees and Alps, eastward to Caspian basin; Aegean basin in Pinios, Vardar, Vegoritis, Kastoria, Struma and Maritza drainages) and Asia (Marmara basin and lower Sakarya in Anatolia, Aral basin, and Siberia from Ob eastward to Lena drainages) (Kottelat and Freyhof, 2007). The species is dominant in many mesotrophic and eutrophic European lakes (Persson, 1993; Persson and Eklov, 1995) and its high adaptive capacity to lentic, lotic and estuarine environments make it one of the most widespread species in Europe (Kottelat and Freyhof, 2007).

Because of its feeding habits, $R$. rutilus can have a significant impact on water quality through accentuating the effects of nutrient enrichment (Ferguson, 2008). Many authors reported that the species has led to a reduction in populations of several fish species through competitive superiority (Johannson and Persson, 1986): rudd Scardinius erythropthalmus (Linnaeus, 1758) have been displaced due to both hybridization and competition (Cragg-Hine, 1973; Griffiths, 1997 ) and in Ireland the introduction of $R$. rutilus has been linked to local extinction of the Arctic charr Salvelinus alpinus (Linnaeus, 1758) and to the severe decline in pollan Coregonus pollan Thompson, 1835 (Ferguson, 2008).

For all these reasons, Froese and Pauly (2013) listed $R$. rutilus as a potential pest based on information in Kottelat and Freyhof (2007).

In Italy $R$. rutilus was locally introduced for recreational aims and its presence was first noticed in Tuscany and later in the Po River Basin (Delmastro and Balma 1991) where it is currently present in subalpine lakes, reservoirs and rivers (Volta and Jepsen, 2008); in Maggiore lake, for example, its abundance increased at a level inducing concern for commercial 


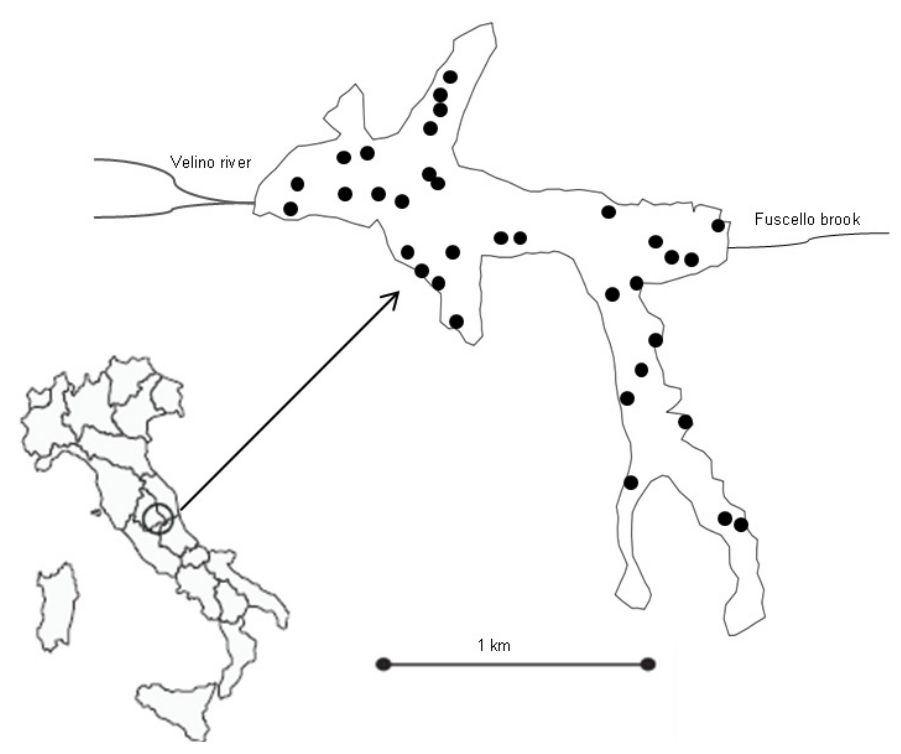

Figure 1

Study area and locations of sampling stations in Piediluco lake.

fishery (Volta, 2007). For Piediluco lake the first record for the species was reported in 2004 (Lorenzoni et al., 2005) and nowadays it is the species most caught in the lake (Lorenzoni et al., 2012).

Knowledge on growth features and determination of catch rates and selectivity of the fishing equipment are crucial steps for the management of an alien species in freshwater ecosystems (Louette and Declerk, 2006). However, in Italy $R$. rutilus has no commercial interest and commercial fishermen generally avoid catching the species. As a result, very little is known on the size selectivity of the capture methods on the population dynamics of this species.

The aim of this research was to collect information on growth of $R$. rutilus and selectivity of gill-nets on this species that could be useful to design a plan to reduce the abundance of this species in Piediluco lake, as well as in other similar environments.

\section{STUDY AREA}

Piediluco lake is a natural lake located in Central Italy (longitude: $0^{\circ} 17^{\prime} 21^{\prime \prime} 0^{\circ} 19^{\prime} 17^{\prime \prime} \mathrm{E}$; latitude: $42^{\circ} 30^{\prime} 54^{\prime \prime}-42^{\circ} 32^{\prime} 28^{\prime \prime} \mathrm{N}$ ) (Figure 1). With a surface area of $1.67 \mathrm{~km}^{2}$, this lake (mean depth $=10.90 \mathrm{~m}$; max. depth $=21.48 \mathrm{~m}$ ) is the second largest natural lake in Umbria Region. Piediluco lake is a regulated lake which has been used for the production of hydroelectric power since 1908. The alkalinity of the lake is $301 \mathrm{mg} \cdot \mathrm{L}^{-1} \mathrm{CaCO}_{3}$ (on surface) and $373 \mathrm{mg} \cdot \mathrm{L}^{-1}$ $\mathrm{CaCO}_{3}$ (on the bottom). The trophic condition of the lake has undergone a rapid change since the 1980s as indicated by total phosphorus data (Cioffi and Gallerano, 2000): the lake was classified as mesotrophic in $1980\left(40 \mu \mathrm{g} \cdot \mathrm{L}^{-1}\right)$ (according to the classification proposed by Vollenweider (1965)), eutrophic in $1989\left(80 \mu \mathrm{g} \cdot \mathrm{L}^{-1}\right)$ and hypertrophic in $1994\left(110 \mu \mathrm{g} \cdot \mathrm{L}^{-1}\right)(\mathrm{ac}-$ cording to the classification proposed by OECD (1982) (Cioffi and Gallerano, 2000) mainly due to an increase in inflow nutrients from its drainage basin (Lorenzoni et al., 2007; La Porta et al., 2010). To date the lake is classified as eutrophic (ARPA, 2013).

The change in water quality and the gradual transition toward a eutrophic status has led to a drastic change in the native fish communities of Piediluco lake (Lorenzoni et al., 2006): only 6 species of the original community (Table I) are still present [eel Anguilla anguilla (Linnaeus, 1758) Southern pike Esox cisalpinus Bianco and Delmastro, 2011, brown trout Salmo trutta Linnaeus,1758, Italian rudd Scardinius hesperidicus Bonaparte, 1845, cavedano chub Squalius squalus (Bonaparte, 1837) and tench Tinca tinca (Linnaeus, 1758)] while Italian roach Rutilus rubilio (Bonaparte, 1837) and three-spined stickleback Gasterosteus aculeatus 
Table I

Temporal evolution of fish community of Piediluco lake from 1996 to 2012.

\begin{tabular}{|l|c|c|c|c|c|}
\hline Family & Species & Origin & 1996 & 2004 & 2012 \\
\hline Anguillidae & Anguilla anguilla (L.,1758) & Native & $\mathrm{X}$ & $\mathrm{X}$ & $\mathrm{X}$ \\
\hline Centrarchidae & Lepomis gibbosus (L.,1758) & Introduced & $\mathrm{X}$ & $\mathrm{X}$ & $\mathrm{X}$ \\
\hline & Abramis brama (L.,1758) & Introduced & & & $\mathrm{X}$ \\
& Alburnus arborella (Bp, 1841) & Introduced & $\mathrm{X}$ & $\mathrm{X}$ & $\mathrm{X}$ \\
& Carassius auratus (L.,1758) & Introduced & & & $\mathrm{X}$ \\
& Cyprinus carpio (L.,1758) & Introduced & & $\mathrm{X}$ & $\mathrm{X}$ \\
& Rutilus rutilus (L.,1758) & Introduced & & $\mathrm{X}$ & $\mathrm{X}$ \\
& Rutilus rubilio (Bp, 1837) & Introduced & $\mathrm{X}$ & $\mathrm{X}$ & \\
& Rutilus aula (Bp, 1841) & Introduced & $\mathrm{X}$ & $\mathrm{X}$ & $\mathrm{X}$ \\
& Scardinius hesperidicus Bp, 1845 & Native & $\mathrm{X}$ & $\mathrm{X}$ & $\mathrm{X}$ \\
& Squalius squalus (Bp, 1837) & Native & $\mathrm{X}$ & $\mathrm{X}$ & $\mathrm{X}$ \\
& Tinca tinca (L., 1758) & Native & $\mathrm{X}$ & $\mathrm{X}$ & $\mathrm{X}$ \\
\hline Esocidae & EsoX cisalpinus Bianco \& Delmastro, 2011 & Native & $\mathrm{X}$ & $\mathrm{X}$ & $\mathrm{X}$ \\
\hline \multirow{2}{*}{ Percidae } & Gymnocephalus cernua (L.,1758) & Introduced & $\mathrm{X}$ & $\mathrm{X}$ & $\mathrm{X}$ \\
& Perca fluviatilis L.,1758 & Introduced & $\mathrm{X}$ & $\mathrm{X}$ & $\mathrm{X}$ \\
\hline \multirow{2}{*}{ Salmonidae } & Coregone lavaretus (L.,1758) & Introduced & $\mathrm{X}$ & $\mathrm{X}$ & $\mathrm{X}$ \\
& Salmo trutta L.,1758 & Native & $\mathrm{X}$ & $\mathrm{X}$ & $\mathrm{X}$ \\
\hline
\end{tabular}

Linnaeus, 1758 can be considered extinct (Lorenzoni et al., 2006); the remaining 11 are all introduced (Lorenzoni et al., 2012). In the 1980s the most commonly caught species were A. anguilla, P. fluviatilis, C. lavaretus and E. cisalpinus (Giovinazzo, 1988), but to date the population of $P$. fluviatilis has decreased and the dominant species in the lake consists mainly of omnivorous cyprinids (Lorenzoni et al., 2012). Among these, $R$. rutilus has successfully acclimatized and now can be considered a stable member of the lake fish community (Lorenzoni et al., 2012).

\section{MATERIALS AND METHODS}

\section{$>$ DATA COLLECTION}

Fish specimens were collected from January 2011 to October 2012 through gill-nets placed seasonally throughout the lake (Figure 1). The sampling was conducted following the protocol of the Lake Fish Index (LFI) (Volta, 2009) that is a multimetric index proposed for the evaluation of the ecological status of Italian lakes according to the EU Water Framework Directive 2000/60 (EU Water Framework Directive, 2000). The LFI sampling protocol is based on a stratified random sampling of the water column and on the definition of random sampling stations (Volta, 2009). The gill-nets used were monofilament multimesh gillnets in nylon (each one $1.5 \mathrm{~m}$ high and $30 \mathrm{~m}$ long) assembled from 12 panels of different-sized mesh arranged in the following sequence: 43, 19.5, 6.25, 10, 55, 8, 12.5, 24, 15.5, 5, 35, $29 \mathrm{~mm}$ (CEN, 2005; Volta, 2009). In addition to the gill-nets suggested in the LFI sampling protocol, two additional mesh sizes (28 and $45 \mathrm{~mm}$ ), set as single panels (CEN, 2005) were used.

According with the LFI protocol, the number of sampling stations and gill-nets were determined on the basis of the area and the maximum depth of the lake (Volta, 2009). A total of 34 sampling stations, randomly located throughout the lake, were selected in Piediluco lake. One benthic gill-net was set at each sampling station perpendicularly to the shore and left for one night (12 h).

For all specimens, the total length (TL) was measured to the nearest $0.1 \mathrm{~mm}$, the weight to the nearest $1 \mathrm{~g}$ (Anderson and Neumann, 1996) and a sample of scales was collected for each specimen for the determination of age by the scalimetric method (Bagenal, 1978). Aging determination was further validated by means of length-frequency distribution (Britton et al., 2004). After all measurements were completed, specimens of roach were retained for further analyses and no fish was released back to lake. 


\section{> GROWTH ESTIMATION}

The regression between total length $(T L)$ and total weight $(W)$ of the specimens was calculated for the total sample of roach by means of the logarithmic equation:

$$
\log _{10} W=a+b \log _{10} T L(\mathrm{~mm}) .
$$

Growth was estimated by the von Bertalanffy growth curve model (von Bertalanffy, 1938):

$$
T L_{t}=L_{\infty}\left(1-e^{\left.-k\left(t-t_{0}\right)\right)}\right.
$$

where $T L_{t}$ is the total length of the fish at time $t, L_{\infty}$ theoretical maximum length $(\mathrm{cm}), k$ is a constant expressing the rate of approach to $L_{\infty}$ and $t_{0}$ is the theoretical age at which $T L_{t}=0$. The index of growth performance $\left(\Phi^{\prime}\right)$ was calculated with the equation of Pauly and Munro (1984):

$$
\Phi^{\prime}=\log _{10} k+2 \log _{10} L_{\infty}
$$

where $k$ and $L_{\infty}$ are the growth parameters of von Bertalanffy model.

\section{$>$ CATCH PER UNIT EFFORT}

The data obtained were used to calculate the "fishing effort" (CPUE = catch per unit effort) (Degerman et al., 1988; Wilderbuer and Kappenman, 1998). The CPUE were calculated separately for each mesh size: the fishing effort was calculated considering both the nets area and the soaking-time. It was also expressed in terms of both number (CPUEs $N=$ ind $\cdot \mathrm{m}^{2} \cdot \mathrm{h}^{-1}$ ) and biomass (BPUEs $=\mathrm{B} \cdot \mathrm{m}^{-2} \cdot \mathrm{h}^{-1}$ ) by means of the following formulas: (Mascarenhas Alves et al., 1998):

$$
\text { CPUE } \mathrm{N}=\mathrm{N} / \mathrm{t} \mathrm{S}
$$

and

$$
\text { BPUE }=B / t \text { S }
$$

where:

$N=$ number of fish caught; $B=$ biomass in grams (g) of fish caught; $S=$ area $\left(\mathrm{m}^{2}\right)$ of the nets; $t=$ soaking-time in hours (h) of nets.

\section{> ANALYSIS OF SIZE SELECTIVITY}

The selectivity analyses were accomplished by means of the indirect method proposed by Holt (1963) as modified by Sparre and Venema (1992). This method allows fitting the gill-net selectivity curves when the size rate of the population under study is unknown Through the indirect method it is possible to assess the selectivity parameters comparing the quantity of fish caught by two different mesh sizes $\left(m_{\mathrm{a}}\right.$ and $\left.m_{\mathrm{b}}\right)$ for the same length class $(L)$ (Sparre and Venema, 1992). According to the method, the contact-selection curves (Millar and Fryer, 1999) was calculated as the natural logarithm $(\mathrm{In})$ of the number of fish caught for each length-group $\left(C_{a}\right.$ and $\left.C_{b}\right)$ by two different mesh sizes with a similar dimensions $\left(m_{a}\right.$ and $\left.m_{b}\right)$ were related to total-length $(L)$ of the specimens through the linear regression (Holt, 1963):

$$
\ln \left(C_{b} / C_{a}\right)=a+b L
$$

where $a$ and $b$ are parameters of the linear regression.

Then, for the mesh sizes $m_{a}$ and $m_{b}$, the optimum lengths $\left(L m_{a}\right.$ and $\left.L m_{b}\right)$, the selection factor (sf) and the standard deviation (sd) were calculated on the basis of the equations (Sparre and Venema, 1992):

$$
\begin{aligned}
L m_{a} & =-2\left(a m_{a}\right) /\left[b\left(m_{a}+m_{b}\right)\right] ; \\
L m_{b} & =-2\left(a m_{b}\right) /\left[b\left(m_{a}+m_{b}\right)\right] ; \\
s f & =-2 a /\left[b\left(m_{a}+m_{b}\right)\right] ; \\
s d & =\left\{-2 a\left(m_{a}+m_{b}\right) /\left[b\left(m_{a}+m_{b}\right)\right]\right\}^{1 / 2} .
\end{aligned}
$$




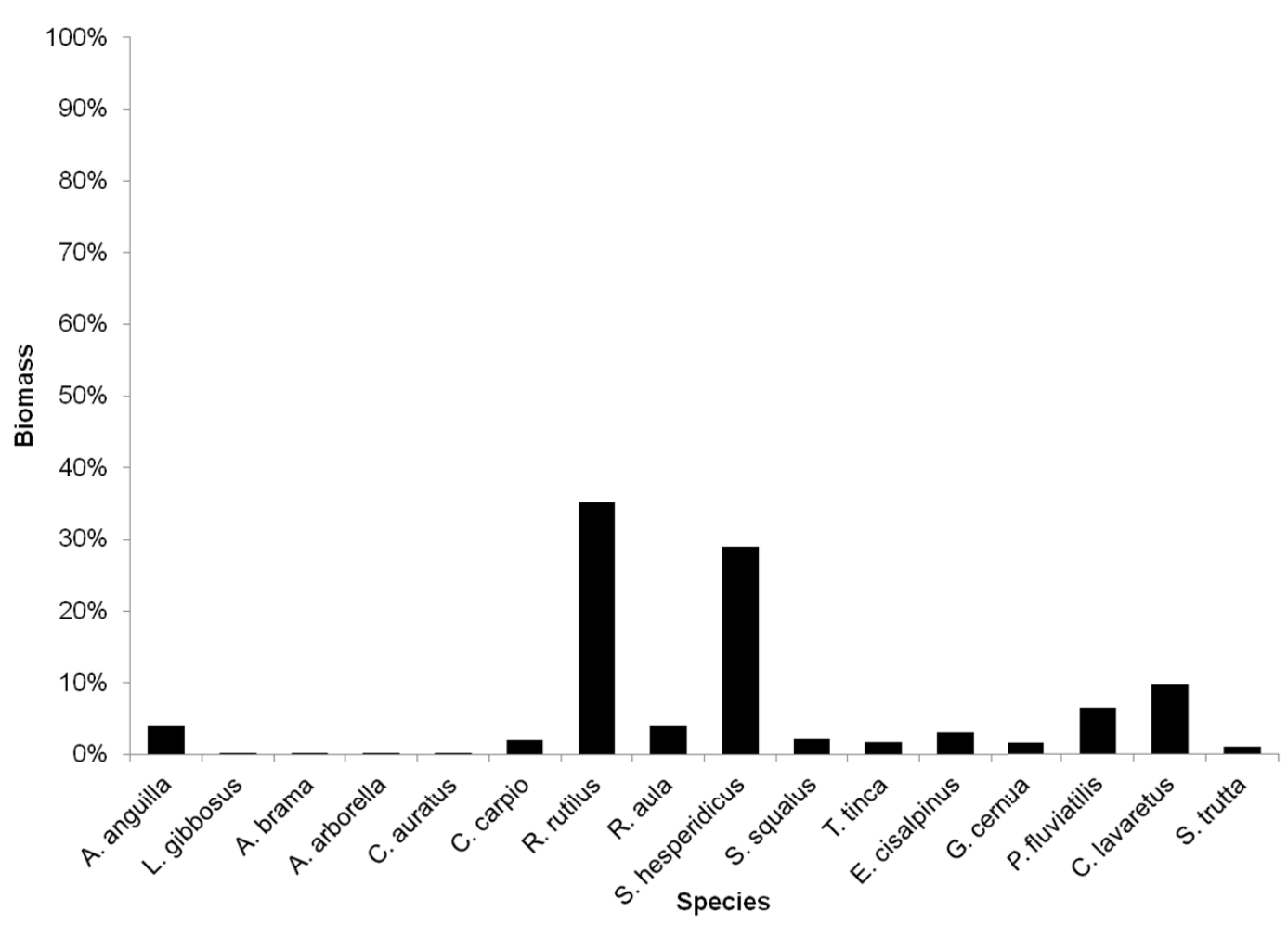

Figure 2

Biomass of each species caught in Piediluco lake by means of gill-nets.

As the number of mesh sizes was greater than two, the common selectivity factor (SF) was accomplished by the formula provided by Sparre et al. (1989):

$$
\left.S F=-2 \sum\left(\left(a_{\mathrm{i}} / b_{\mathrm{i}}\right)\left(m_{\mathrm{i}}+m_{\mathrm{i}+1}\right)\right) / \sum\left(m_{\mathrm{i}}+m_{\mathrm{i}+1}\right)^{2}\right) \text { for } i=1 \text { to } n-1
$$

and the standard deviation (SD) was computed as the mean value calculated for each consecutive pair of mesh sizes $m_{a}$ and $m_{b}$ (Sparre and Venema, 1992):

$$
S D=\left(1 /(n-1) \sum\left(\left(2 a_{i}\left(m_{i+1}-m_{i}\right)\right) /\left(b^{2}\left(m_{i}+m_{i+1}\right)\right)\right)^{1 / 2} .\right.
$$

The optimum length $(L m)$ represented the $100 \%$ probability of capture for each mesh and it was determined for each mesh size $m$ using the equation (Sparre and Venema, 1992):

$$
L m=S F m \text {. }
$$

Finally, assuming a normal curve of selection the probability of capture $(P)$ for a given length $L$ in a gill-net with a mesh size $m$ was calculated by the relationship (Sparre and Venema, 1992):

$$
P=\exp -\left((L-L m)^{2} / 2 S D^{2}\right) \text {. }
$$

\section{RESULTS}

A total of 16 fish species and 9837 individual fish were captured during the study using gillnets (Figure 2). A total of $1963 R$. rutilus were captured representing $35.20 \%$ of the total biomass. The sample of $R$. rutilus ranged in length from $5.0 \mathrm{~cm}$ to $42.4 \mathrm{~cm}$ (mean $\pm \mathrm{SD}=$ $19.57 \pm 8.34 \mathrm{~cm}$ ) (Figure 3a), in weight from $1.50 \mathrm{~g}$ to $1190 \mathrm{~g}$ (mean $\pm \mathrm{SD}=162.06 \pm 184.94 \mathrm{~g})$ and in age from $0+$ to $9+$ years (Figure $3 b$ ). 

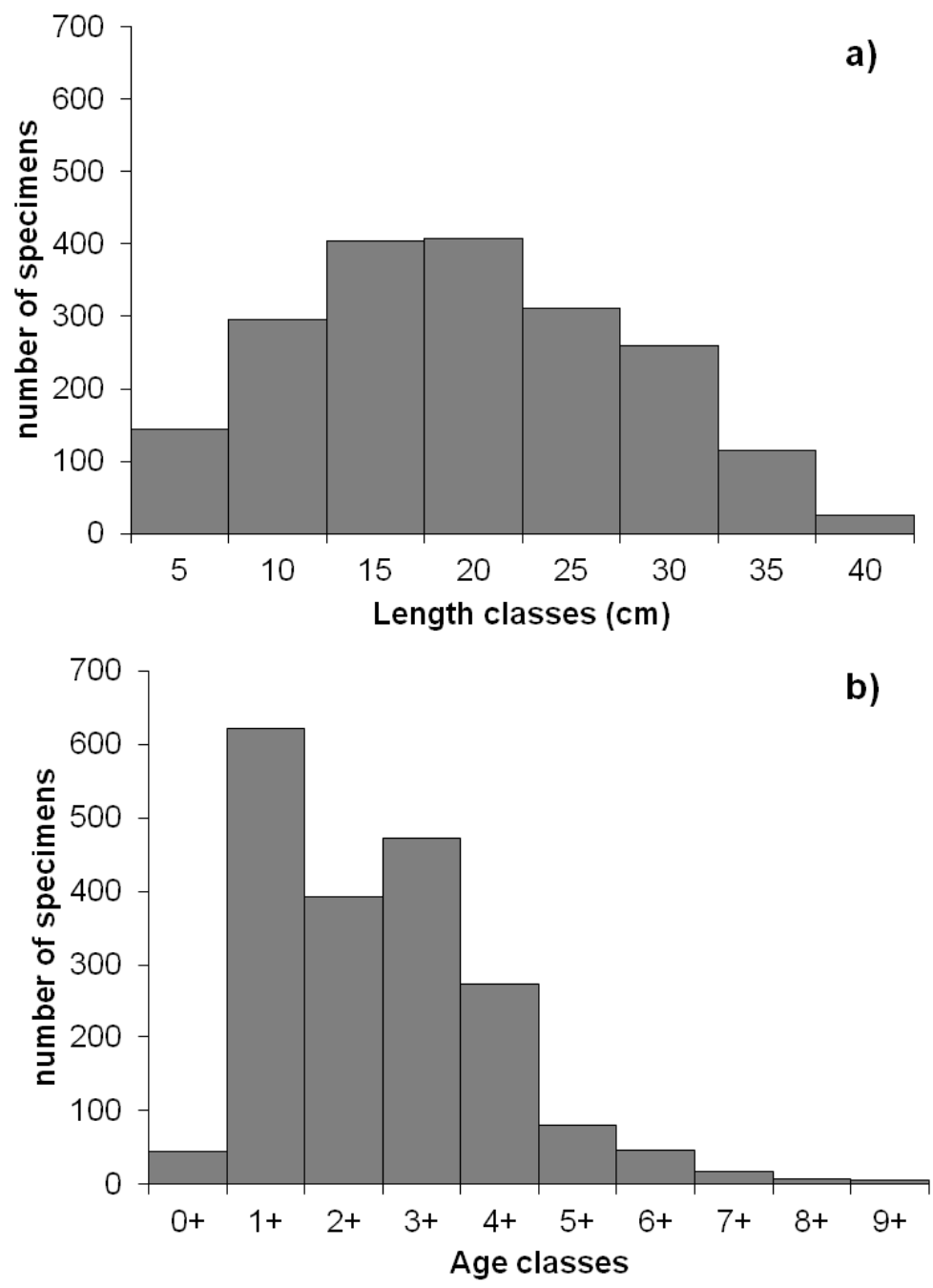

Figure 3

Length (a) and age (b) frequency distribution of roach in Piediluco lake.

The logarithmic $T L-W$ equation for the total sample of roach was:

$$
\log _{10} W=-2.138+3.194 \log _{10} T L\left(R^{2}=0.994\right) .
$$

The resulted Von Bertalanffy growth function for roach was:

$$
T L_{t}=47.820\left(1-e^{-0.237(t-0.302)}\right)\left(R^{2}=0.931\right) .
$$

The growth performance index $\Phi^{\prime}$ for roach resulted 2.734 .

The mean value of CPUE was 0.244 ind $\cdot \mathrm{h}^{-1} \cdot \mathrm{m}^{-2}$ while the mean value of BPUE was $39.438 \mathrm{~g} \cdot \mathrm{h}^{-1} \cdot \mathrm{m}^{-2}$ for $R$. rutilus.

By analysing the percentage of $R$. rutilus caught for each age class by each mesh size (Table II), the panels with a small mesh size were more selective than those with a large mesh size: the nets of 35,45 and $55 \mathrm{~mm}$ mesh size caught fish belonging to different ageclasses (1+ to $9+)$ while the nets with a smaller mesh size caught mostly younger specimens. It confirmed that the age of the specimens caught increase with the mesh size used.

Regression parameters (slope and intercept), coefficient of optimum length and selectivity parameters (selection factors and standard deviation) were assessed for each combination of mesh size and were reported in Table III. The common selectivity factor (SF) for roach was 7.53 while the common standard deviation (SD) was 4.33 . The optimum selection lengths 
Table II

Percentage of specimens of roach caught with each mesh size divided by age-classes (Age) on Piediluco lake.

\begin{tabular}{|c|c|c|c|c|c|c|c|c|c|c|}
\hline & \multicolumn{10}{|c|}{ Mesh size } \\
\hline Age & 8 & 10 & 12.5 & 15.5 & 19.5 & $\overline{24}$ & 28 & $\overline{35}$ & $\overline{45}$ & 55 \\
\hline $0+$ & 91.02 & 70.73 & 10.22 & - & 0.77 & - & - & - & - & - \\
\hline $1+$ & 8.98 & 25.61 & 89.78 & 96.30 & 67.69 & 23.62 & - & 1.04 & - & - \\
\hline $2+$ & - & 2.44 & - & 1.23 & 22.31 & 60.63 & 12.11 & 4.66 & - & - \\
\hline $3+$ & - & 1.22 & - & 1.85 & 3.08 & 8.66 & 67.37 & 39.90 & 4.69 & 16.67 \\
\hline $4+$ & - & - & - & - & 2.31 & 4.72 & 16.32 & 43.01 & 38.54 & 25.00 \\
\hline $5+$ & - & - & - & 0.62 & 3.85 & 0.79 & 2.63 & 7.77 & 30.73 & 8.33 \\
\hline $6+$ & - & - & - & - & - & 1.57 & 1.58 & 3.11 & 15.10 & 25.00 \\
\hline $7+$ & - & - & - & - & - & - & - & - & 5.73 & 16.67 \\
\hline $8+$ & - & - & - & - & - & - & - & - & 3.13 & - \\
\hline $9+$ & - & - & - & - & - & - & - & 0.52 & 2.08 & 8.33 \\
\hline
\end{tabular}

\section{Table III}

Selectivity parameters of gill-nets used for catch roach in Piediluco lake.

\begin{tabular}{|l|c|c|c|c|c|c|c|c|}
\hline \multicolumn{2}{|c|}{ Mesh size } & \multicolumn{7}{c|}{ Selectivity parameters } \\
\hline$m_{a}$ & $m_{b}$ & $a$ & $b$ & $R^{2}$ & $L m_{a}$ & $L m_{b}$ & Sf & Sd \\
\hline $\mathbf{8}$ & 10 & -4.236 & 0.476 & 0.681 & 7.902 & 9.877 & 9.877 & 4.146 \\
\hline $\mathbf{1 0}$ & 12.5 & -18.552 & 1.663 & 0.986 & 9.913 & 12.392 & 9.913 & 1.489 \\
\hline $\mathbf{1 2 . 5}$ & 15.5 & -12.703 & 0.995 & 0.774 & 11.400 & 14.136 & 9.120 & 2.750 \\
\hline $\mathbf{1 5 . 5}$ & 19.5 & -11.565 & 0.735 & 0.862 & 13.931 & 17.526 & 8.987 & 4.889 \\
\hline $\mathbf{1 9 . 5}$ & 24 & -2.299 & 0.133 & 0.312 & 12.322 & 15.166 & 7.949 & 26.898 \\
\hline $\mathbf{2 4}$ & 28 & -4.417 & 0.224 & 0.597 & 18.188 & 21.220 & 7.578 & 13.520 \\
\hline $\mathbf{2 8}$ & 35 & -5.903 & 0.221 & 0.671 & 23.755 & 29.694 & 8.484 & 26.884 \\
\hline $\mathbf{3 5}$ & 45 & -6.184 & 0.215 & 0.516 & 25.216 & 32.421 & 7.205 & 33.573 \\
\hline $\mathbf{4 5}$ & 55 & -8.340 & 0.246 & 0.592 & 30.463 & 37.232 & 8.769 & 35.590 \\
\hline
\end{tabular}

Table IV

Optimum selection lengths for each mesh size estimated by the model for roach of Piediluco lake.

\begin{tabular}{|c|c|c|c|c|c|c|c|c|c|c|}
\hline & \multicolumn{10}{|c|}{ Mesh size } \\
\hline & 8 & 10 & 12.5 & 15.5 & 19.5 & 24 & 28 & 35 & 45 & 55 \\
\hline Lm & 6.025 & 7.531 & 9.413 & 11.673 & 14.685 & 18.074 & 21.086 & 26.358 & 33.889 & 41.419 \\
\hline
\end{tabular}

estimated by the model for each mesh size were summarized in Table IV while the resulted selection curve of gill-nets yielded by the probability of capture were illustrated in Figure 4. A linear relationship was observed between the total length of the specimens and the mesh size of the gill-net:

$$
m=1.138 T L(\mathrm{~cm})+0.608\left(R^{2}=0.715 ; p<0.001\right) .
$$

This confirms that the size of $R$. rutilus caught rose with the increasing of the net mesh size. The resulting relationship was statistically significant $(p<0.001)$.

\section{DISCUSSION}

Currently R. rutilus is one of the most widespread fish species in Europe (Kottelat and Freyhof, 2007). Because of the high ecological adaptability and the small interest by commercial fishermen, the species is able to acclimatize successfully in new environments and can become predominant in fish community. $R$. rutilus can competes with other species such as S. erythrophthalmus (Niederholzer and Hofer, 1980; Volta and Jepsen, 2008) more sensitive to environmental changes (Garcia-Berthou and Moreno-Amich, 2000; Ravera and Jamet, 1991). In Piediluco lake the population of $R$. rutilus has significantly increased in recent years: in 1999 the species was absent in the lake; in 2004 it represented only 4.82\% (Lorenzoni et al., 2012), 


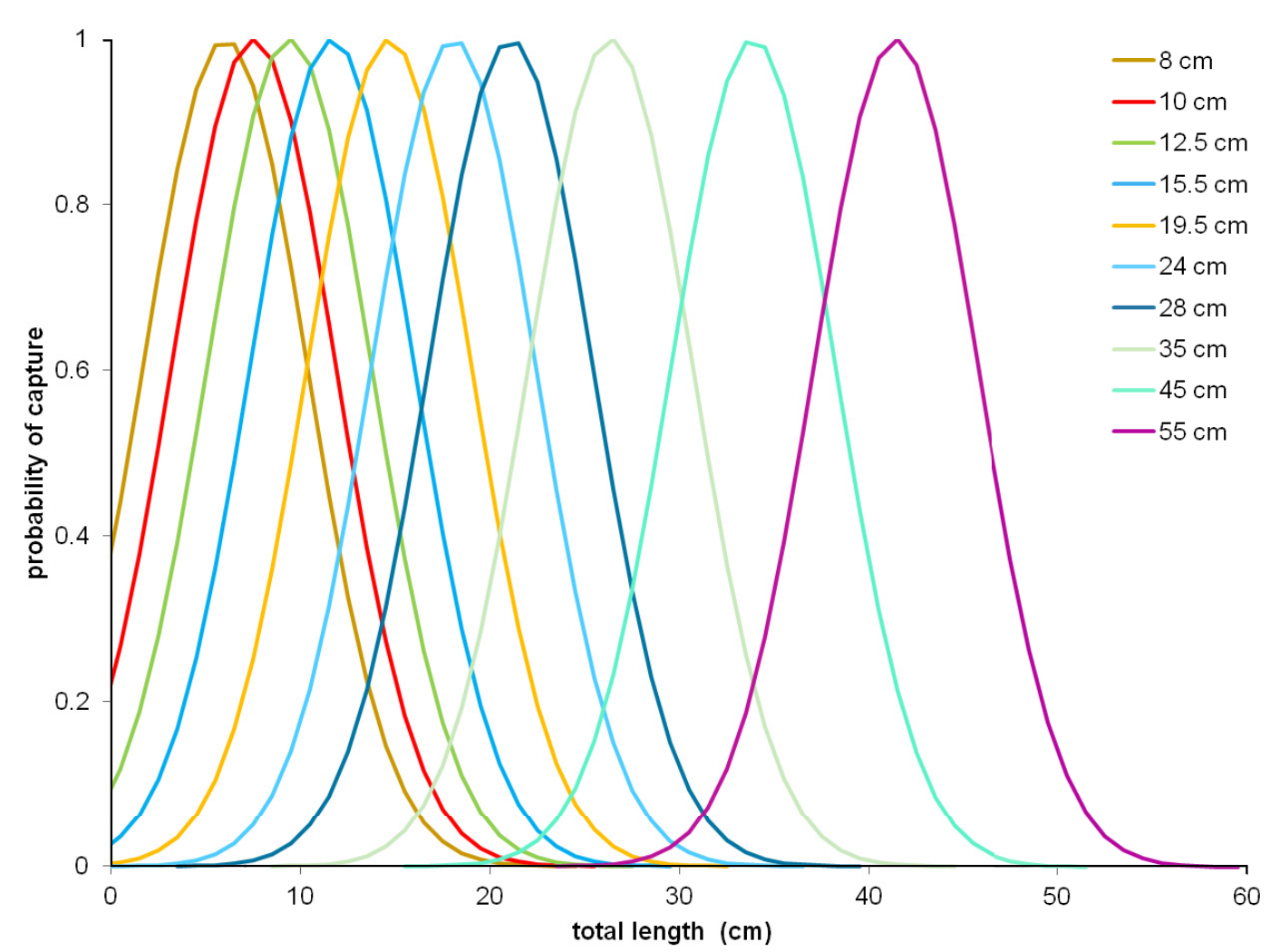

Figure 4

Selectivity curves of gillnets.

\section{Table $V$}

Parameters of the von Bertalanffy regressions and $\Phi^{\prime}$ values for roach populations from different countries. (L. =lake).

\begin{tabular}{|l|c|c|c|c|c|c|}
\hline Country & Locality & $L_{\infty}(\mathrm{cm})$ & $K$ & $t_{0}$ & $\Phi^{\prime}$ & References \\
\hline France & Geneve L. & 34.400 & 0.210 & -0.260 & 2.400 & Ponton and Gerdeaux, 1990 \\
\hline Greece & Volvi L. & 33.300 & 0.080 & -1.300 & 1.950 & Kleanthidis and Stergiou, 2006 \\
\hline Italy & Piediluco L. & 47.820 & 0.237 & 0.302 & 2.734 & present research \\
\hline Italy & Maggiore L. & 35.750 & 0.290 & -0.400 & 2.550 & Volta and Jepsen, 2008 \\
\hline Kazakhstan & Aral L. & 51.300 & 0.100 & & 2.420 & Pauly, 1978 \\
\hline Poland & Dabie L. & 26.300 & 0.156 & -1.172 & 2.030 & Wiesky and Zalachovsky, 2000 \\
\hline Romania & Razim L. & 40.000 & 0.210 & - & 2.530 & Staras et al., 1995 \\
\hline Russian Fed. & Petschora & 42.500 & 0.080 & - & 2.160 & Pauly, 1978 \\
\hline Switzerland & Lugano L. & 36.800 & 0.300 & - & 2.610 & Guthruf, 2002 \\
\hline
\end{tabular}

while in the present research $R$. rutilus reached $35.20 \%$ of total biomass captured. While in 2004 only 5 age classes were found (Lorenzoni et al., 2012), in the present research 10 age classes were found The parameters of the von Bertalanffy equation of the population in Piediluco lake also showed a rapid growth: the growth of $R$. rutilus was higher and faster than in other lakes (Table V). In Piediluco lake, the value of $\Phi^{\prime}$ (that indicated the quality of the growth) also was higher than those of others populations inhabiting eutrophic lake environments (i.e. Geneva lake (Ponton and Gerdeaux, 1987) and Lugano lake (Guthruf, 2002)). However, this could be due to differences in other parameters (i.e.: alkalinity class or size category) since the growth of fish can also change with increasing alkalinity The value of $\Phi^{\prime}$ found for roach in Piediluco lake was also higher than that reported for the roach population of Maggiore lake (Volta and Jepsen, 2008) in Northen Italy (the only value available in 
literature for Italian populations of roach). However these differences can also depend on the different trophic status being Maggiore lake oligo-mesotrophic (Volta and Jepsen, 2008). The high value of $\Phi^{\prime}$ found in the present research, confirmed the species ability to expand and to adapt to the environmental conditions of Piediluco lake. This ecological trait of roach represents a threat for this environment, as this could lead to a further worsening of water quality through predation of $R$. rutilus on zooplankton (Lorenzoni et al., 2006). Moreover this expansion of $R$. rutilus also represents a strong threat for those fish species such as $S$. esperidicus that were firstly advantaged by the change in the trophic status of the lake. To this regard, Lorenzoni et al. (2012) reported that the small number of young specimens of $S$. esperidicus caught in Piediluco lake indicated a structure typical of a population in regression despite the abundance of the specie resulted constant over time.

The determination of monofilament gillnet selectivity parameters is an important tool for the management of a species (Ozekinci et al., 2007).

Gillnet selection curves for roach were estimated by other authors (i.e.: Borgstrøm, 1989; Kurkilahti and Rask, 1998; Kurkilahti, 1999; Prchalová et al., 2009) by means of the "twopeaked model" (Hovgård and Lassen, 2000). In the present study, the classical "bell-shaped model" (Holt, 1963) modified by Sparre and Venema (1992) was used.

For each of the mesh size combinations the selection factors ranged between 7.20 and 9.91 while the common selectivity factor was 7.53. These values are in line with Andreev (1962) who asserted that this parameter generally varies between 5 and 10 .

Knowledge on selectivity of the nets represents one of the most important tools for fishery management (Louette and Declerk, 2006; Ozekinci et al., 2007). The high selectivity of gill nets permits to use specific mesh sizes to catch a suitable narrow size range of fish (Hamley, 1975; Borgstrøm, 1989; Petrakis and Stergiou, 1995). With regard to invasive species, this information is very useful to allow fishery managers to catch the size classes that mainly contribute to population recruitment (Lorenzoni et al., 2010)

Currently no detailed information is known on the reproductive biology of $R$. rutilus in Piediluco lake but the results of other studies (conducted in other environments where the species was introduced) reported that the species reached sexual maturity at $12.3 \mathrm{~cm}$ for male and $15 \mathrm{~cm}$ for female (2+ age class) in Sapanca lake (an oligotrophic lakes in Turkey) (Tarkan, 2006); at the age class of $1+$ for male and 2+ for female in Volvi lake (an eutrophic lake in Greece) (Papageorgiou, 1979). The only information available in literature for Italy refers to Maggiore lake (an oligo-mesotrophic lake) where the species reaches the sexual maturity at a total length of $17.0 \mathrm{~cm}$ for male and $19.3 \mathrm{~cm}$ for female (at 2+ age-class) (Volta and Jepsen, 2008). According to these results, the nets showing the highest probability to catch specimens that have reached the sexual maturity (1+ and 2+ age classes) were those of $24 \mathrm{~mm}, 19.5 \mathrm{~mm}$ and $15.5 \mathrm{~mm}$. On the contrary, gill nets with a mesh size bigger than $28 \mathrm{~mm}$ caught specimens belonging to the older classes.

The choice of the best strategy for the management of an invasive species often results difficult. In such cases it is important to compare costs/benefits against the probability of success (Myers et al., 2000). According to this, the first step to design a plan to control an invasive species is a preliminary analysis of the practical possibilities to use the catching tools and the knowledge of their true effectiveness in the field (Koehn, 2003).

The present study represented this preliminary analysis. The results provided useful information on growth of $R$. rutilus in Piediluco lake and the determination of monofilament gill-nets selectivity parameters. This study had an extra value because it represents the first reference on size selectivity of gill-nets for the roach in Italy, the most southern region where the species is present.

Further knowledge on reproductive biology of this species, together with the extension of size selectivity analysis to the other dominant fish species present in Piediluco lake, will allow fishery managers to design a plan for the management of $R$. rutilus population thereby reducing its abundance and limiting its impact on other fish species. 


\section{REFERENCES}

Andersen M.C., Adams H., Hope B. and Powell M., 2004. Risk Assessment for Invasive Species. Risk Analysis, 24, 787-793.

Anderson R.O. and Neumann R.M., 1996. Length, weight and associated structural indices. In: Murphy B.R. and Willis D.W. (eds.), Fisheries techniques. American Fisheries Society, Bethesda, 447-483.

Andreev N.N., 1962. Handbook of Fishing Gear and its Rigging. Pishchepromizdat, Moscow, 454 p.

ARPA Umbria, 2013. L'acqua in Umbria. Disponibilità, consumo e salute. Le rappresentazioni e gli atteggiamenti dei cittadini. ARPA Umbria, Perugia, $200 \mathrm{p}$.

Bagenal T.B., 1978. Fish production in fresh waters. Ed. Blackwell, Oxford, 250 p.

Bianco P.G. and Keitmaier V., 2001. Anthropogenic changes in the freshwater fish fauna of Italy, with reference to the central region and Barbus graellsii, a newly established alien species of Iberian origin. J. Fish Biol., 59 (Suppl A), 190-208.

Borgstrøm R., 1989. Direct estimates of gillnet selectivity for roach (Rutilus rutilus) in a small lake. Fish. Res., 7, 289-298.

Britton J.R., Cowx I.G. and Peirson G., 2004. Sources of error in the ageing of stocked cyprinids. Fisheries Manag. Ecol., 11, 415-417.

Byers J.E., Reichard S., Randall J.M., Parker I.M., Smith C.S., Lonsdale W.M., Atkinson I.A.E., Seastedt T.R., Williamson M., Chornesky E. and Hayes D., 2002. Directing research to reduce the impacts of non-indigenous species. Conserv. Biol., 16, 630-640.

Cioffi F. and Gallerano F., 2000. Response of lake Piediluco to the change of hydrodynamic conditions and nutrient load reductions. Ecol. Modell. 135, 199-229.

Cragg-Hine D., 1973. Coarse fish and fisheries management in Northern Ireland. In Proceedings of the sixth British coarse fish conference. University of Liverpool, UK, pp. 52-59.

Degerman E., Nyberg P. and Appelberg M., 1988. Estimating the number of species and relative abundance of fish in oligotrophic Swedish lakes using multi-mesh gillnets. Nord J. Freshwat. Res., 64, 91-100.

Delmastro G.B. and Balma G.A.C., 1991. Nota sulla comparsa del ciprinide transalpino Rutilus rutilus (Linnaeus, 1758) nelle acque piemontesi. Riv. Idrobiol., 29, 163-167.

EU Water Framework Directive, 2000. Directive 2000/60/EC of the European Parliament and the Council of 23 October 2000. Establishing a framework for community action in the field of water policy. Official Journal of the European Communities. (22.12.2000): L 327, 1.

Ferguson A., 2008. Invasive Alien Species in Northern Ireland. Available: http://www.habitas.org.uk/ invasive/species.asp?item $=5029$.

Froese R. and Pauly D., 2013. FishBase. World Wide Web electronic publication. www.fishbase.org, version (04/2013).

Garcia-Berthou E. and Moreno-Amich R., 2000. Rudd (Scardinius erythrophthalmus) introduced to the Iberian peninsula: feeding ecology in Lake Banyoles. Hydrobiologia, 436, 159-164.

Giannetto D., Carosi A., Franchi E., Pedicillo G., Pompei L. and Lorenzoni M., 2012. Assessing the impact of non-native freshwater fishes on native species using relative weight. Knowl. Managt. Aquatic. Ecosyst., 404 (03).

Giovinazzo G., 1988. La pesca e l'accrescimento di Perca fluviatilis (L.). Riv. Idrobiol., 27, 729-740.

Griffiths D., 1997. The status of the Irish freshwater fish fauna: a review. J. Appl. Ichthyol., 13, 9-13.

Guthruf J., 2002. Die Biologie des Routages im Luganersee (Kanton TI). Buwal, Mitteilungen zur Fuscherei, 74, 90.

Hamley J.M, 1975. Review of gill net selectivity. J. Fish. Res. Board of Canada, 32, 1943-1969.

Helfman G.S., 2007. Fish Conservation: The Degradation and Restoration of Biodiversity, Island Press.

Holt S.J., 1963. A method for determining gear selectivity and its application. ICNAF Spec. Publ., 5, 106-115.

Hovgård H. and H. Lassen 2000. Manual on estimation of selectivity for gillnet and longline gears in abundance surveys. FAO Fish. Tech. Pap. No. 397, Rome, 84.

Johannson L. and Persson L., 1986. Planktivorous fish. In: Riemann B. and Sondergaard M. (eds.), Carbon dynamics in eutrophic temperate lakes. Elsevier Science, Amsterdam, 237-266. 
Koehn J., 2003. Rationale results and management implications of recent carp research in Australia. Proceedings of the workshop: Managing invasive freshwater fish in New Zealand, 10-12 May 2001, Hamilton, 85-94.

Kottelat M. and Freyhof J., 2007. Handbook of European freshwater fishes. Cornol, 646 p.

Kurkilahti M., 1999. Nordic Multimesh Gillnet-Robust Gear for Sampling Fish Populations. University of Turku, Helsinki, p. 108.

Kurkilahti M. and Rask M., 1998. A comparative study of the usefulness and catchability of multimesh gill nets and gill net series in sampling of perch (Perca fluviatilis L.) and roach (Rutilus rutilus L.). Fish. Res., 27, 243-260.

La Porta G., Angeli V., Bicchi A., Carosi A., Pedicillo G., Viali P., Lorenzoni M., 2010. Variations in the fish community in Lake Piediluco (Italy) caused by changes in the lake's trophic status and the introduction of alien species. J. Appl. Ichthyol., 26 (Suppl. 2), 53-59.

Lorenzoni M., Pedicillo G., Bolotti G.M., Carosi A., Angeli V., Bicchi A. 2005. Monitoraggio ittico del lago di Piediluco. Università di Perugia, Perugia.

Lorenzoni M., Ghetti L. and Mearelli M., 2006. Native and exotic fish species in the Tiber River watershed (Umbria-Italy) and their relationship to the longitudinal gradient. Bull. Fr. Pêche Piscic., 382, 19-44.

Lorenzoni M., Carosi A., Pedicillo G., Trusso A., 2007. A comparative study of the feeding competition of the European perch Perca fluviatilis L. and the ruffe Gymnocephalus cernua (L.) in lake Piediluco (Umbria, Italy). Bull. Fr. Pêche Piscic., 387, 35-57.

Lorenzoni M., Pace R., Pedicillo G., Viali P., Carosi A., 2009. Growth, catches and reproductive biology of ruffe Gymnocephalus cernuus in Lake Piediluco (Umbria, Italy). Folia Zool., 58, 420-435.

Lorenzoni M., Dolciami R., Ghetti L., Pedicillo G.; Carosi A. 2010. Fishery biology of the goldfish Carassius auratus (Linnaeus, 1758) in lake Trasimeno (Umbria, Italy). Knowl. Managt. Aquatic. Ecosyst., 396, 01.

Lorenzoni M., Carosi A., Franchi E., Giannetto D., Pompei L., Viali P., 2012. Andamento delle abbondanze del gardon (Rutilus rutilus, Linnaeus, 1758) nel lago di Piediluco. XIV congresso nazionale A.I.I.A.D. Turin, November 15-17 2012, Italy.

Louette G. and Declerk S., 2006. Assessment and control of non-indigenous brown bullhead Ameiurus nebulosus populations using fyke nets in shallow ponds. J. Fish. Biol., 68, 522-531.

Mack R.N., Simberloff D., Lonsdale W.M., Evans H., Clout M. and Bazzaz F.A., 2000. Biotic invasions: causes, epidemiology, global consequences, and control. Ecol. Appl., 10, 689-710.

Mascarenhas Alves C.B., Lima Godinho A., Pereira Godinho H., Campos Torquato V., 1998. A Ictiofauna da represa de Itutinga, Rio Grande (Minas Gerais - Brasil). Rev. Brasil. Biol., 58, 121-129.

McKinney M.L. and Lockwood J.L., 1999. Biotic homogenization: a few winners replacing many losers in the next mass extinction. Trend in Ecology and Evolution, 14, 450-453.

Millar R.B. and Fryer R.J., 1999. Estimating size-selection curves of trawls, traps, gillnets and hooks. Rev. Fish Biol. Fish., 9, 89-116.

Myers J.H., Simberloff D., Kuris A.M. and Carey J.R., 2000. Eradication revisited: dealing with exotic species. Trends Eco. Evol., 15, 316-320.

Niederholzer R. and Hofer R., 1980. The feeding of roach (Rutilus rutilus L.) and rudd (Scardinius erythrophthalmus L.), I. Studies on natural populations. Ekol. Pol. 28, 45-59.

Ozekinci U., Altinagac U., Ayaz A., Cengiz O., Ayyildiz H., Kaya H. and Odabasi D., 2007. Monofilament gillnet selectivity parameters for European chub (Leuciscus cephalus L., 1758) in Atikhisar Reservoir, Canakkale, Turkey. Pak. J. Biol. Sciences, 10, 1305-1308.

Papageorgiou N.K., 1979. The length weight relationship, age, growth and reproduction of the roach Rutilus rutilus (L.) in lake Volvi. J. Fish Biol., 14, 529-538.

Pauly D., 1978. A preliminary compilation of fish length growth parameters. Ber. Inst. Meereskd. Christian-Albrechts-Univ. Kiel 55, 1-200.

Pauly D. and Munro J.L., 1984. Once more on the comparison of growth in fish and invertebrates. Fishbyte 2, 21.

Persson L., 1993. Effects of intra- and interspecific competition on resource on dynamics and size structure of a perch Perca fluviatilis and roach Rutilus rutilus population. Oikos 41, 126-132.

Persson L. and Eklöv P., 1995. Prey refuges affecting interactions between piscivorous perch and juvenile perch and roach. Ecology, 76, 70-81. 
Petrakis G. and Stergiou K.I., 1995. Gill net selectivity for Diplodus annularis and Mullus surmuletus in Greek waters. Fish. Res., 2, 1455-1464.

Ponton D. and Gerdeaux D., 1987. La population du gardon (Rutilus rutilus(L.)) du lac leman en 1983-85. Structure en age, determinisme du recrutement, analyse de la croissance. Bull. Fr. Pêche Piscic., 305, 43-53.

Prchalováa M, Kubečkaa J., Ríhaa M., Mrkvičkaa T., Văseka M, Juzaa T., Kratochvíl M., Peterkaa J., Draštíka V., Kř́žzekd J., 2009. Size selectivity of standardized multimesh gillnets in sampling coarse European species. Fish. Res., 96, 51-57.

Ravera O. and Jamet J.L., 1991. The diet of the rudd (Scardinius erythrophthalmus, L.) in relation to the possible consequences for the removal of this species from an eutrophic lake. Arch. Hydrobiol., 123, 99-109.

Riccardi R., 1955. Il lago di Piediluco ed il suo bacino. Mem. Soc. Geogr. Ital., 22, 115-195.

Sparre P. and Venema S.C., 1992. Introduction to Tropical Fish Stock Assessment, Part I, FAO Tech. Pap., 306, 175-181.

Sparre P., Ursin E. and Venema S.C., 1989. Introduction to Tropical Fish Stock Assessment, Part I, FAO Fish. Tech. Pap., 306, 337.

Tarkan A.S., 2006. Reproductive ecology of two cyprinid fishes in an oligotrophic lake near the southern limits of their distribution range. Ecol. Freshw. Fish, 15, 131-138.

Volta P., 2007. Biologia di Rutilus rutilus (Linneo, 1758) nel Lago Maggiore. In: Atti del Congresso Congiunto AIOL-SItE, Ecologia, limnologia e oceanografia: quale futuro per l'ambiente? Ancona 17-20 settembre 2007, 49-59.

Volta P., 2009. Indice per l'analisi dello stato di qualità della fauna ittica finalizzato alla valutazione dello stato ecologico dei laghi italiani: Lake Fish Index (LFI). In: Indici per la valutazione della Qualità ecologica dei laghi. CNR, Istituto per lo Studio degli Ecosistemi. Verbania Pallanza.

Volta P. and Jepsen N., 2008. The recent invasion of Rutilus rutilus (L.) (Pisces: Cyprinidae) in a large South-Alpine lake: Lago Maggiore. J. Limnol., 67, 163-170.

von Bertalanffy L. 1938. A quantitative theory of organic growth. Hum. Biol., 10, 181-213.

Welcomme R.L., 1988. International introductions of inland aquatic species. FAO Fish. Tech. Pap., 213, 120.

Wilderbuer T.K. and Kappenman R.F., 1998. Analysis of Fishing Power Correction. Factor Estimates from a Trawl Comparison Experimental. N. Am. J. Fish. Manage, 18, 11-18. 